\title{
Five new species of sarcophagid flies from Fiji and Solomon Islands (Diptera, Sarcophagidae)*
}

\author{
Satoshi Shinonaga** and Rokuro Kano** \\ Department of Medical Zoology, Faculty, of Medicine, Tokyo Medical and \\ Dental University, Bunkyo-ku, Tokyo 113, Japan
}

(Received: July 15, 1992)

Key words: Sarcophagidae, new species, Fiji, Solomon Islands.

\begin{abstract}
Five new sarcophagid flies are described and figured from Fiji and Solomon Islands. These are Sarcophaga malaitensis, $S$. isorokui, $S$. nigridorsalis, $S$. tephroides, and S. vitilevensis.
\end{abstract}

\section{INTRODUCTION}

Definition of the genera belonging to Sarcophaginae differs according to authors who studied in different geographic regions. Verves (1986) proposed 16 genera from the Palaearctic region followed Rohdendorf's opinion and Lopes (1990) listed 15 genera from the Australasian region. Sugiyama and Kano (1984) proposed a new system of classification of Oriental sarcophagine flies. They combined recorded 16 genera into 3 genera, Blaesoxipha, Helicophagella and Sarcophaga. In the present paper, we cited Sugiyama and Kano's system for Australasian species.

Among the species described in this paper, tephroides and vitilevensis belong to the genus Fijimyia Lopes et Kano and the other 3 species are classified into the genus Sarcorohdendorfia Lopes.

In the present paper, we describe 2 species from Fiji and 3 species from the Solomon

* This study was supported by the Grant-in-Aid for Overseas Scientific Survey from the Ministry of Education, Science and Culture, Japan, in 1975, to Tokyo Medical and Dental University (Grant No. 7715).

** 策永 哲, 加納六郎: 東京医科歯科大学医学部医 動物学教室（干113 東京都文京区湯島 1-5-45）
Islands.

\section{DesGriptions}

\section{Sarcophaga tephroides, n. sp.}

(Fig. 1)

Male. Body length about $13 \mathrm{~mm}$. Yellowish in colour.

Head: Frons $0.19-0.20$ of head width at narrowest part; frontal vitta black; parafrontalia and parafacialia golden pruinose; ori 10-12, lower 2-3 divergent below; antenna black, 3rd segment about twice as long as 2nd; arista dark brown, feathered on basal two-thirds; palpus dark brown; anterior part of gena with black hairs, posterior part before genal groove with white hairs; metacephalon and occiput with white hairs.

Thorax: Scutum grayish pollinose with three longitudinal stripes; $a c 0+1 ; d c 5-6+5$ (posterior two of post $d c$ strong); ia $0+2$; prs $0-1$; h 3; ph 2; np 4; sa 3 ; pa 2; aps 1 ; $d s 1$; ls 2 ; st $2+1$; propleuron bare.

Wings: Hyaline; wing base and anterior half reddish; $r_{1}$ bare; $r_{4+5}$ with short setae; squama brown.

Legs: Black; $t_{1}$ with 2 ad and $1 p v ; t_{2}$ with $1 a d, 3 p d$ and $1 p l ; t_{3}$ with $3 a d$ and $2 p d, 1 a v ; a v$ and $p v$ surface of $t_{3}$ with long curled hairs. 

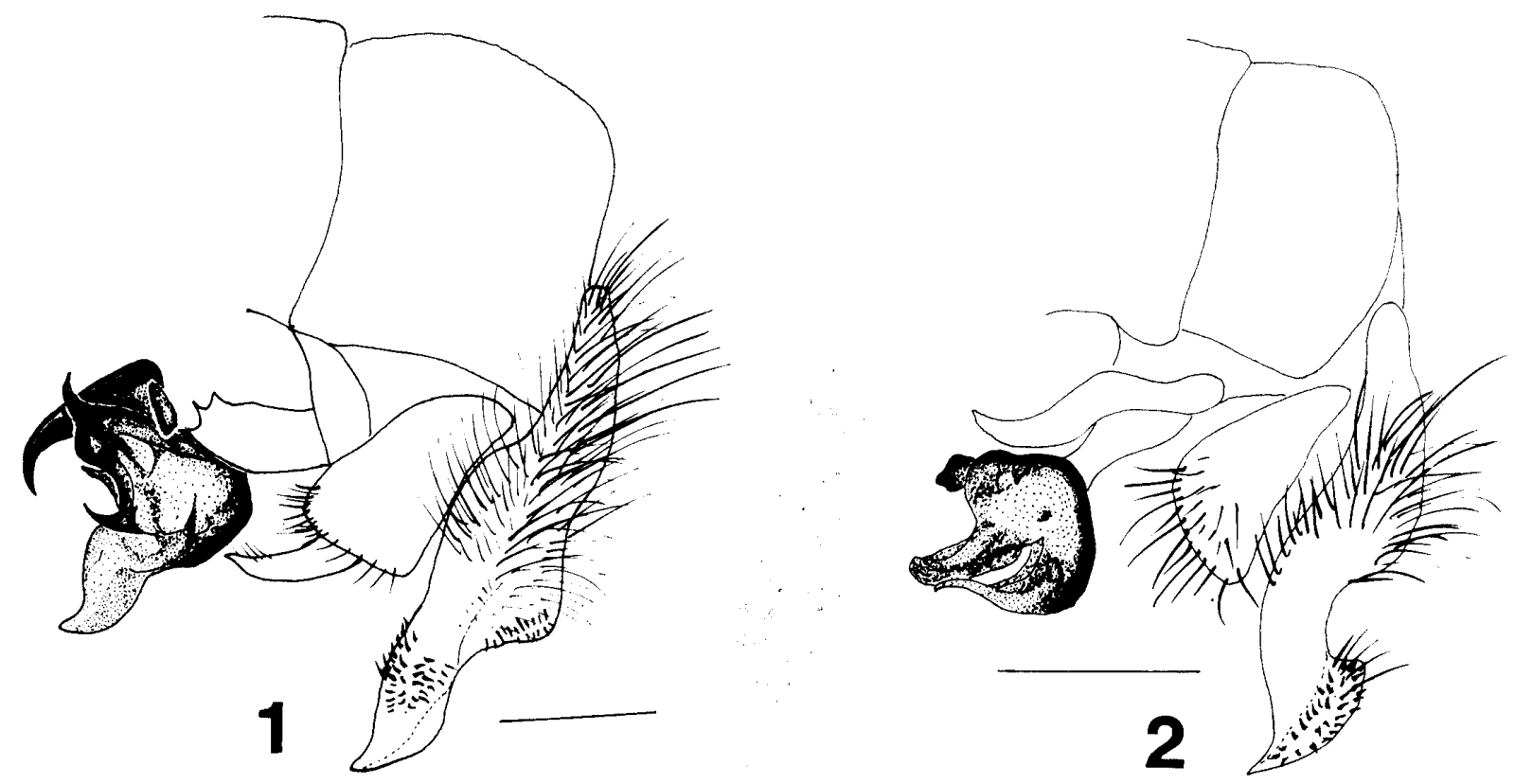

Fig. 1 Sarcophaga tephroides, n. sp.

Male genitalia (lateral view).

Fig. 2 Sarcophaga vitilevensis, n. sp.

Male genitalia (lateral view).

Abdomen: Black with silvery checkered pattern, 4th and 5th tergites black with white dust; 3rd and 4th segment with strong median marginal bristles; 1 st to 4 th sternites without long hairs; 5 th sternite $\mathrm{V}$-shaped, black.

Genitalia: Epandrium brown and slightly dusted dorsally; cercus broad and pointed with short spines as in figure; surstylus triangular; theca short; harpes strongly sclerotized and pointed; vesica sclerotized, large and pointed.

Female. Unknown.

Holotype. Male, $25 \mathrm{~km} \mathrm{~N}$ of Vatukarasa, Viti Levu, $700 \mathrm{~m}$, Fiji, 9 March 1978, S. Shinonaga. Type in National Science Museum, Tokyo.

Remarks. The present species is closely related to Sarcophaga tephrula Bezzi, but is easily differentiated by the shape of genitalia.

\section{Sarcophaga vitilevensis, n. sp.}

(Fig. 2)

Male. Body length $7 \mathrm{~mm}$.

Head: Frons $0.19-0.20$ of head width at narrowest part; frontal vitta black; parafrontalia and parafacialia silvery pruinose; ori 11-12, lower 2-3 divergent below; an- tenna black, 3rd segment about twice as long as 2nd; arista dark brown, feathered on basal two-thirds; palpus dark brown; anterior part of gena with black hairs, posterior part before genal groove with white hairs; metacephalon and occiput with white hairs.

Thorax: Scutum grayish pollinose with three longitudinal stripes; ac $0+1 ; d c 4-5+$ 3 ; ia $0+2$; prs $0-1 ; h 3$; ph 2 ; np 4; sa 3 ; pa 2 ; aps 1 ; ds 1 ; ls 2 ; st $2+1$; propleuron bare.

Wings: Hyaline; wing base and anterior half reddish; $r_{1}$ bare; $r_{4+5}$ with short setae; squama brown.

Legs: Black; $t_{1}$ with $2 a d$ and $1 p v ; t_{2}$ with $2 a d, 3 p d$ and $1 p l ; t_{3}$ with $3 a d$ and $2 p d, 1 a v$; $a v$ and $p v$ surface of $t_{3}$ without long curled hairs.

Abdomen: Black with silvery checkered pattern, 4th and 5th tergites black with white dust; 3rd segment without median marginal bristles; 1st to 4th sternites without long hairs; 5th sternite V-shaped, black.

Genitalia: Epandrium black and slightly dusted dorsally; cercus broad and pointed with short spines as in figure; surstylus triangular; theca short; vesica short and sclerotized, large and pointed. 


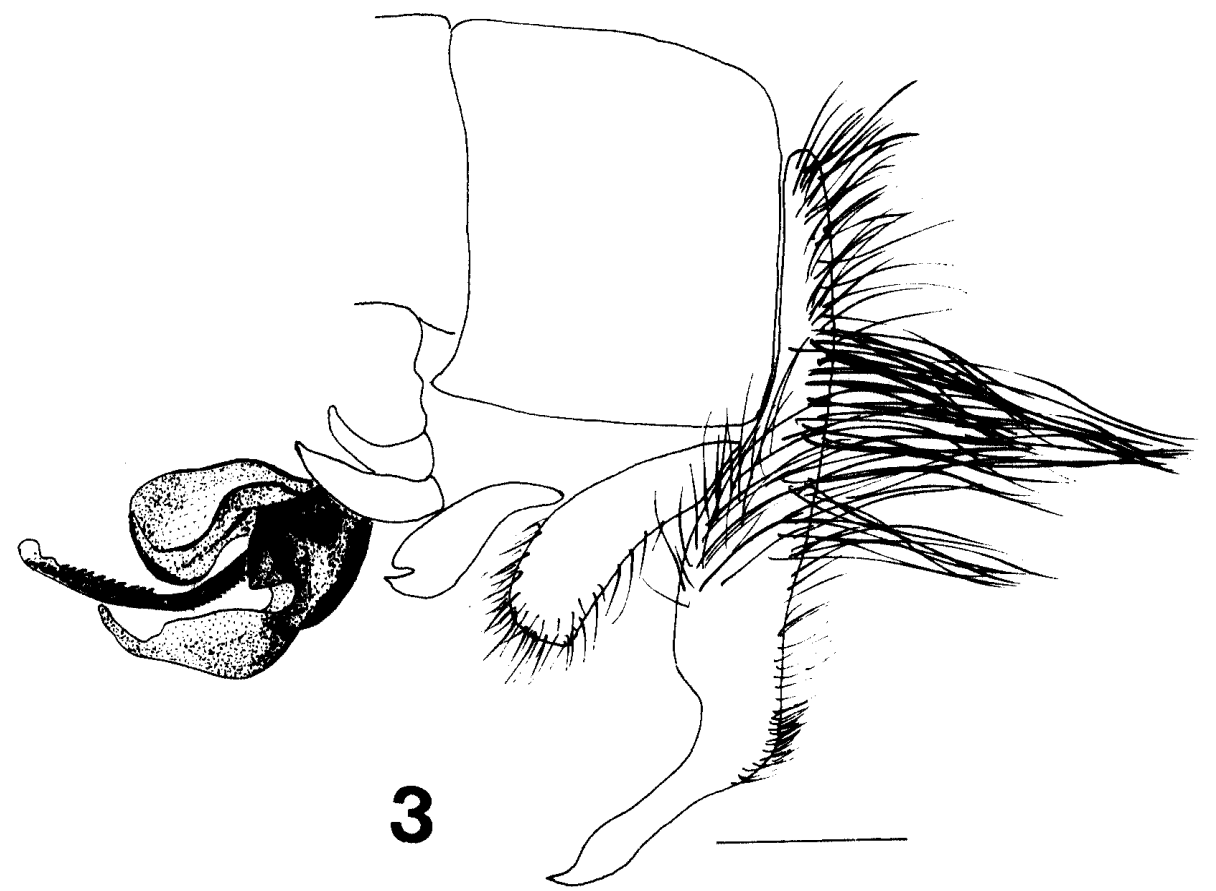

Fig. 3 Sarcophaga malaitensis, n. sp.

Male genitalia (lateral view).

Female. Unknown.

Holotype. Male, Nausori Highland, 500 m, Viti Levu I., Fiji, 7-8 March 1978, S. Shinonaga. Type in National Science Museum, Tokyo.

Remarks. This species belongs to the genus Fijimyia Lopes et Kano in shape of cercus, however, it is easily differentiated from Sarcophaga tephrula and S. tephroides by the shape of phallic structure.

\section{Sarcophaga malaitensis, n. sp. (Fig. 3)}

Male. Body length about $18 \mathrm{~mm}$. Blackish fly.

Head: Frons about 0.2 of head width at narrowest part; frontal vitta black; parafrontalia and parafacialia golden pruinose; ori 12-13, lower 2-3 divergent below; antenna dark brown, 3rd segment about 2.5 times as long as 2nd; arista dark brown, feathered on basal two-thirds; palpus dark brown; gena and metacephalon golden in colour with golden hairs; anterior edge of parafacialia black with short black setae.

Thorax: Scutum golden pollinose with three longitudinal stripes; $a c 0+1 ; d c 4+4$; ia $0+2$; prs $1 ; h 3$; ph 2 ; np 4; sa 4 ; pa 2 ; aps 1 ; ds 1 ; ls 2 ; st $2+1$; propleuron with numerous black hairs.

Wings: Hyaline; wing base and anterior half infuscated; $r_{1}$ bare; $r_{4+5}$ with short setae; squama brown.

Legs: Black; $t_{1}$ with $1 \mathrm{ad}$; $t_{2}$ with $1 \mathrm{ad}$ and $1 p l$, ventral surfaces covered with medium-sized hairs on distal two-thirds; $t_{3}$ with $2 a d, 1 a d$ and $1 a v, a v$ and $p v$ surface of $t_{3}$ with long curled hairs.

Abdomen: Black with silvery and golden checkered pattern, 4th and 5th tergites black with white dust; 3rd and 4th segment with median marginal bristles; 1 st to 4 th sternites without long hairs, 4th sternite with patch of hairs; 5th sternite V-shaped, black.

Genitalia: Epandrium brown and slightly dusted dorsally; cercus bending anteriorly; surstylus triangular; theca short; vesica large and not strongly sclerotized; stylet long with short spines; juxta pointed apically.

Female. Unknown.

Holotype. Male, Maluu, Malaita Island, Solomon Islands, 27 January 1978, S. Shinonaga. Type in National Science Museum, Tokyo.

Remarks. This species belongs to genus Sarcorohdendorfia Lopes in having hairy propleuron and patch of hairs on 4th sternite. 


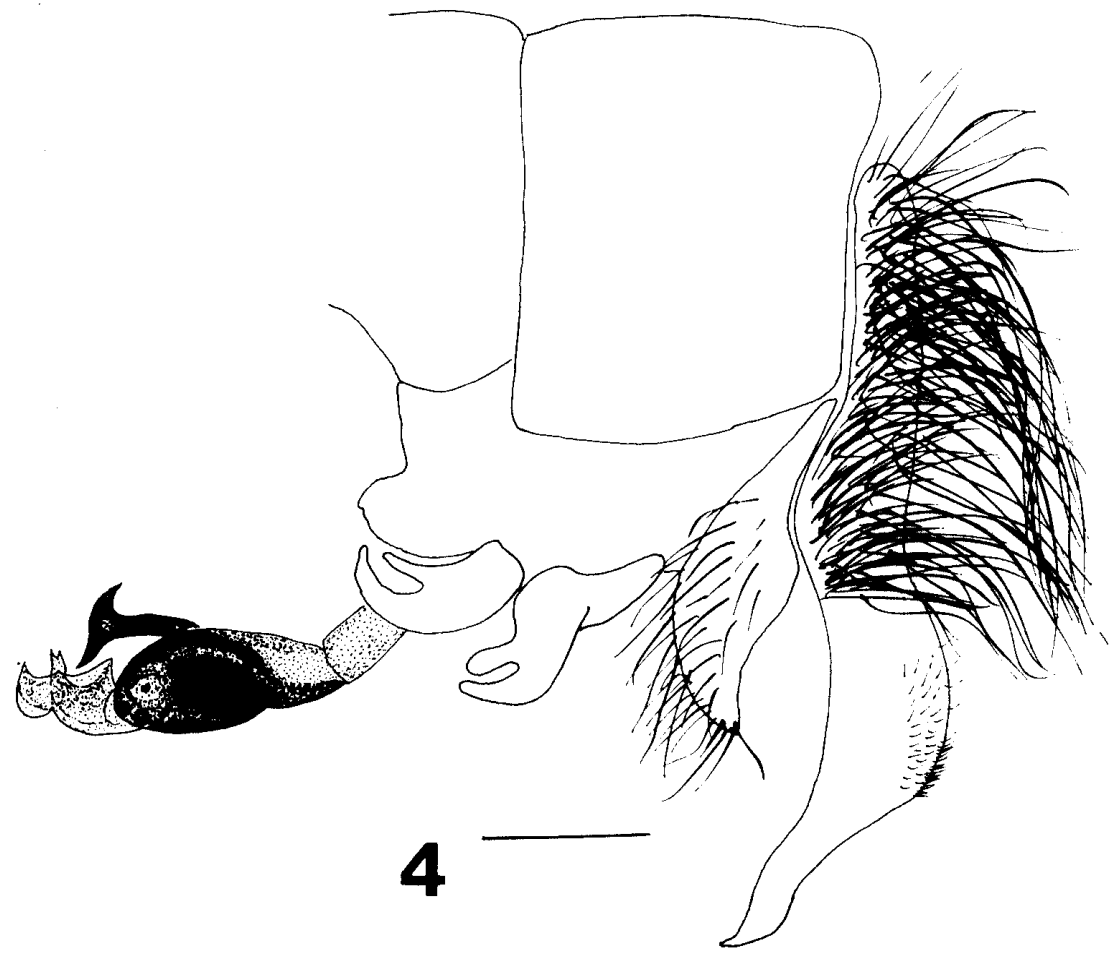

Fig. 4 Sarcophaga nigridorsalis, n. sp.

Male genitalia (lateral view).

The species is easily differentiated from other species in having black abdominal tergites and characteristic phallic structure.

\section{Sarcophaga nigridorsalis, n. sp.} (Fig. 4)

Male. Body length about $18 \mathrm{~mm}$. Blackish species.

Head: Frons about 0.15 of head width at narrowest part; frontal vitta black; parafrontalia and parafacialia golden pruinose; ori 12, lower 2-3 divergent below; antenna dark brown, 3rd segment about 2.5 times as long as 2nd; arista dark brown, feathered on basal two-thirds; palpus dark brown; gena and metacephalon golden in colour with golden hairs; anterior edge of parafacialia black with short black setae.

Thorax: Scutum golden pollinose with three longitudinal stripes; ac $0+1 ; d c 6+4$; ia $0+2$; prs $1 ; h 2$; ph 2 ; np 4; sa 4 ; pa 2 ; aps 1 ; ds 1 ; ls 2 ; st $1+1$; propleuron with numerous yellow hairs.

Wings: Dark infuscate along veins; anterior half darker; $r_{1}$ bare; $r_{4+5}$ with short setae; squama brown.

Legs: Black; $t_{1}$ with $2 a d$, ventral surface with numerous long hairs curled apices; $t_{2}$ without setae, ventral surfaces covered with numerous long hairs curled apices on entire length; $t_{3}$ with $2 \mathrm{ad}$ and $1 \mathrm{ad}$, long curled hairs on $a v$ and $p v$ surface.

Abdomen: Metallic black, slightly covered with white dust on dorsal surface of 5 th tergite; 4th tergite with median marginal bristles; 1 st to 4 th sternites covered with short hairs, 4th sternite with patch of hairs; 5 th sternite $\mathrm{V}$-shaped.

Genitalia: Epandrium brown and slightly dusted dorsally; cercus bending anteriorly; surstylus triangular; theca short; vesica large and strongly sclerotized and pointed; stylet short; juxta membraneous apically.

Female. Unknown.

Holotype. Male. $8 \mathrm{~km} \mathrm{E}$ of Dala, Malaita Island, Solomon Islands, 25-26 January 1978, S. Shinonaga. Holotype is deposited in National Science Museum, Tokyo.

Remarks. The present species belongs to the genus Sarcorohdendorfia Lopes in its patch of hairs on 4th sternite. This species is easily distinguished from other species in having black wings and abdomen and also by the shape of genitalia. 


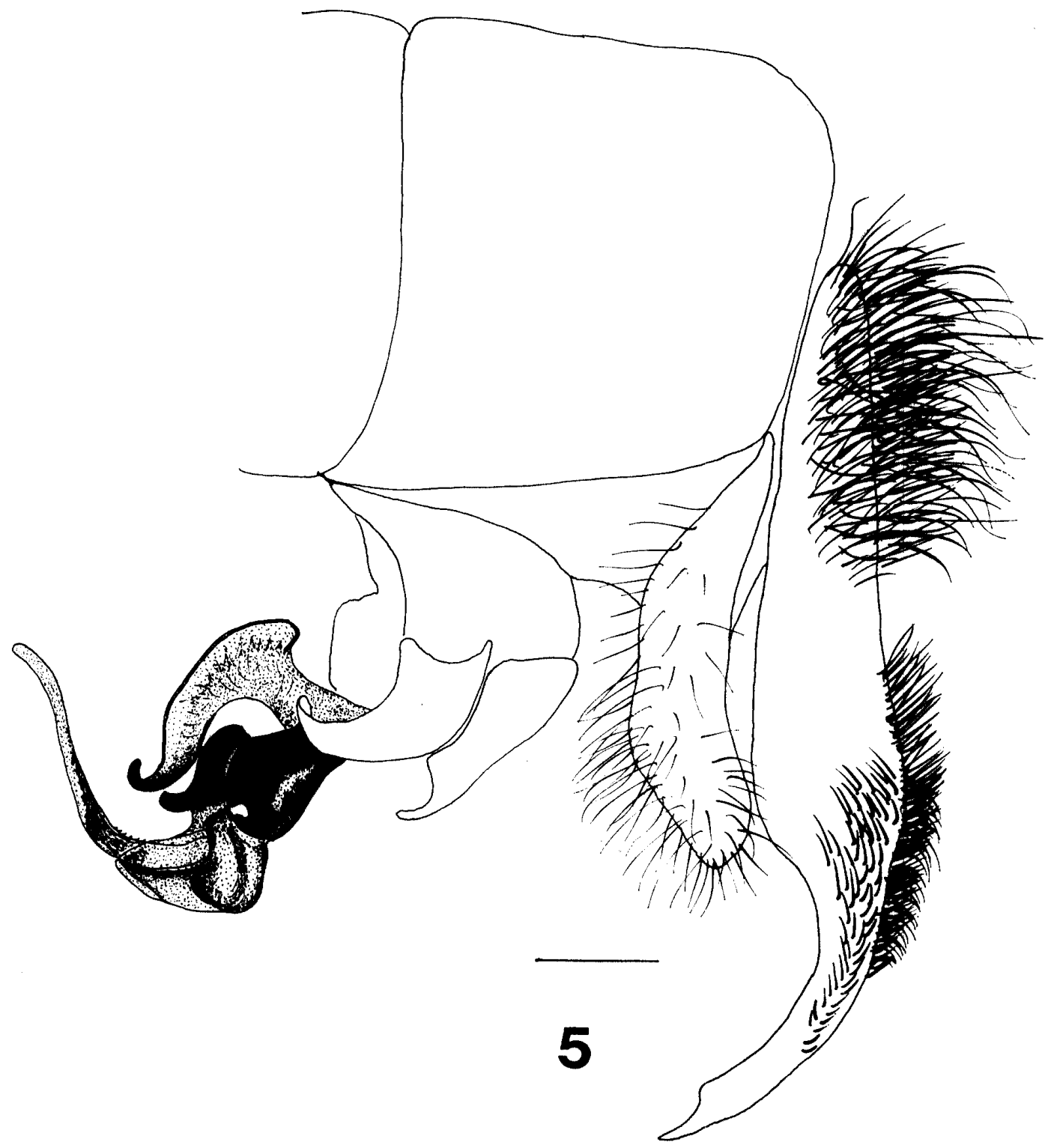

Fig. 5 Sarcophaga isorokui, n. sp.

Male genitalia (lateral view).

\section{Sarcophaga isorokui, n. sp.} (Fig. 5)

Male. Body length $22 \mathrm{~mm}$. Large and golden fly.

Head: Frons about 0.18 of head width at narrowest part; frontal vitta black; parafrontalia and parafacialia golden pruinose; ori 16 , lower 2-3 divergent below; antenna dark brown, 3rd segment about 2.5 times as long as 2nd; arista dark brown, feathered on basal two-thirds; palpus black; gena and metacephalon golden in colour with golden hairs; anterior edge of parafacialia with short black setae.

Thorax: Scutum golden pollinose with three longitudinal stripes; ac $0+1 ; d c 6+4$; ia $0+2$; prs 1 ; $h 2$; ph $1 ; n p 4$; sa 3 ; pa 2 ; aps 1 ; ds 1 ; ls 2 ; st $0+1$; propleuron with numerous yellow hairs.

Wings: Hyaline, anterior half slightly infuscate; $r_{1}$ bare; $r_{4+5}$ with short setae; squama brown.

Legs: Black; $t_{1}$ without setae, anteroventral surface with numerous long hairs; $t_{2}$ without setae, ventral surfaces covered with numerous long hairs curled apices on entire length; $t_{3}$ with $2 a d$ and $1 a d$, long curled hairs on $a v$ and $p v$ surfaces. 
Abdomen: Golden yellow, with brownish checkered patern and black median longitudinal stripes; 4th tergite with median marginal bristles; 1 st to 4 th sternites covered with long hairs, 4th sternite with patch of hairs; 5 th sternite $\mathrm{V}$-shaped.

Genitalia: Epandrium black, without dust; cercus bending anteriorly, with short hairs and spines; theca short; vesica large; basal part of paraphallus strongly sclerotized; stylet very long more than 2.5 times as long as juxta.

Female. Unknown.

Holotype. Male. Kieta, 0-30 m, Bougainville Island, Papua New Guinea, 17-20 January 1978, H. Kurahashi. Type specimen is deposited in National Science Museum, Tokyo.

Remarks. The present species belongs to the genus Sarcorohdendorfia Lopes in its patch of hairs on 4th sternite. This species is closely related to Sarcophaga longistylata Lopes, but is easily distinguished from it by its pointed ventralia.

\section{AGKNOWLEDGEMENTS}

We wish to express our sincere thanks to the late Dr. J. L. Gressitt, B. P. Bishop Museum, for his kind co-operation with our research; to $\mathrm{Mr}$. H. K. Paia, Permanent Secretary, Ministry of Education and Cultural Affairs, Republic of Solomon Islands, for sanctioning our field work; to Dr. $\mathrm{H}$.
H. Chen of WHO in Honiara and Mr. Takayama of Honiara for their kind help in various ways.

\section{REFERENCES}

Lopes, H. S. (1990): Family Sarcophagidae. In: Catalog of the Diptera of the Australasian and Oceanian Regions (ed., Evenhuis, N.L.), pp. 721-732, Bishop Museum Press and E. J. Brill, Honolulu.

Sugiyama, E. and R. Kano (1984) : Systematics of the Sarcophaginae of the Oriental region based on the comparative morphology of the male genitalia (Diptera, Sarcophagidae). Jpn. J. Sanit. Zool., 35: 343-356.

Verves, Yu. G. (1986): Family Sarcophagidae. In: Catalogue of Palaearctic Diptera, Calliphoridae-Sarcophagidae (ed., Soós, A. and L. Papp), Vol. 12, pp. 58-193, Académiai Kiadó, Budapest.

$$
\begin{gathered}
\text { 摘 要 } \\
\text { フィジーおよびソロモン群島の } \\
\text { ニクバェ } 5 \text { 新種 }
\end{gathered}
$$

フィジーおよびソロモン群島において二クバエの 5 新種をみいだした。フィジーの2 種は，口ペスの Fijimyia 属にあたる種で, ソロモン群島の 3 種は, Sarcorohdendorfia 属に属する種である。しかし，本 論文では, 杉山・加納 (1984) の東洋区のニクバエ亜 科の属の定義に従って, 両属ともに Sarcophaga属に 分類した. 新種は, S. tephroides, S. vitilevensis ( イジー), S. malaitensis, S. nigridorsalis, S. isorokui (ソロモン) である。 